\title{
J. Perinat. Med. Prenatal diagnosis and therapy of fetal heart rate anomalies: 8 (1980) 203 With a contribution on the placental transfer of Verapamil
}

\author{
F. Wolff, K. H. Breuker, K. H. Schlensker, A. Bolte
}

Dept. of Obstetrics and Gynecology, University of Köln (Co-Directors: Professor R. Kaiser, A. Bolte)

The prenatal fetal diagnosis of heart rate anomalies is made by fetal electrocardiography $[1,2]$. Arrhythmias as well as heart rate anomalies have been described; incidence and clinical significance have been reported elsewhere $[1,2,11]$. In this study of three individual cases the diagnosis and therapy of fetal heart rate anomalies will be discussed. In one of the cases a paroxysmal fetal tachycardia was treated successfully. One of the drugs used was Verapamil and its use offered the opportunity to investigate its placental transfer which had previously been unknown in the human.

\section{Cases}

Case 1: M.W., 21 year-old II Para after Cesarean Section three years before. She was admitted one day before her due date because a fetal bradycardia was noted on auscultation. The cardio-
Curriculum vitae

Dr. FRIEDRICH WOLFF was born in 1947 and studied at the Medical School of Düsseldorf University; state examination and registration in 1973. Since 1975, he has been an assistant at the University of Cologne, Department of Gynecology and Obstetrics. His research interests are concentrated on investigations concerning the prevention and treat ment of premature birth.

gram demonstrated a persistent fetal bradycardia of 70 to 80 beats/minute. The fetal ECG (Fig. 1) documented a bradycardia with a rate of 72 to 78 beats/minute. An AV block was suspected. On the next day labor began and a Cesarean section was

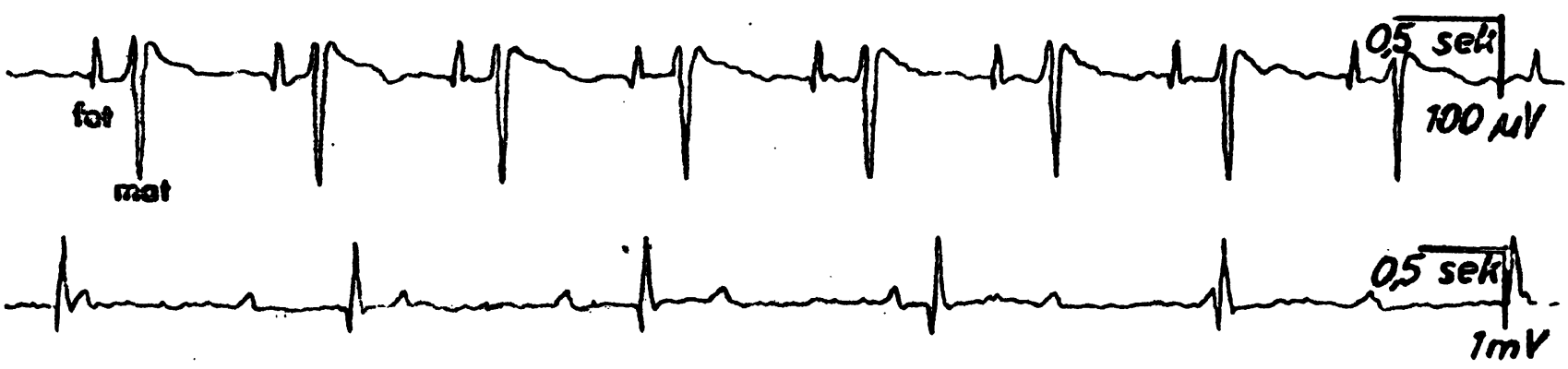

Fig. 1. Above: prenatal fetal ECG in the 40th week of gestation: fetal bradycardia with complete AV block. Rate $72-80$ per minute, amplitude $68.0 \mu \mathrm{V}$. Below: neonatal ECG postpartum with continuous AV block. 
performed. A healthy appearing boy with a birth weight of 3400 gram, length $51 \mathrm{~cm}$, APGAR score 8 at one minute was born. An electrocardiogram obtained immediately after birth (fig. 1, below) confirmed the complete AV block with complete dissociation of atrial and ventricular activity. The AV block converted spontaneously into a normal conduction after one week; no cause of the rhythm disturbance was found.

Case 2: A.S., 27 year-old primigravida four days before her EDC. A fetal ECG demonstrated extra- systoles (Fig. 2) with a rate of 132 to 156 beats/ minute. Because of the fetal maturity and a favorable cervix (BisHOP score 5) the birth was induced with amniotomy and oxytocin infusion $(8 \mathrm{mE} /$ min). Fetal heart rate was recorded continuously from a scalp electrode and labor was recorded from intra-amniotic pressure recordings (HewlettPackard cardiotocograph 8030A). During delivery irregularly occurring extrasystoles were seen on the oscilloscope, simultaneously the recorder registered unidirectional excursions of constant

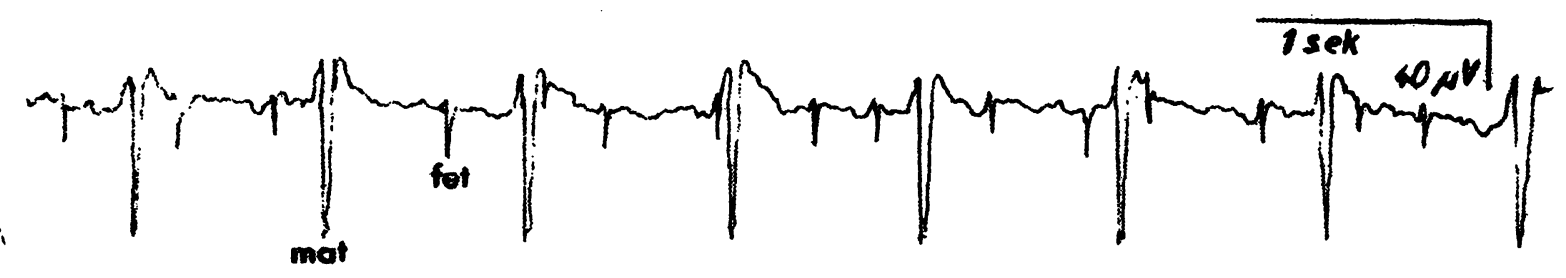

Fig. 2. Prenatal ECG in the 40 th week of gestation. Fetal extrasystoles, rate $132-156$ per minute, amplitude $70.0 \mu \mathrm{V}$.
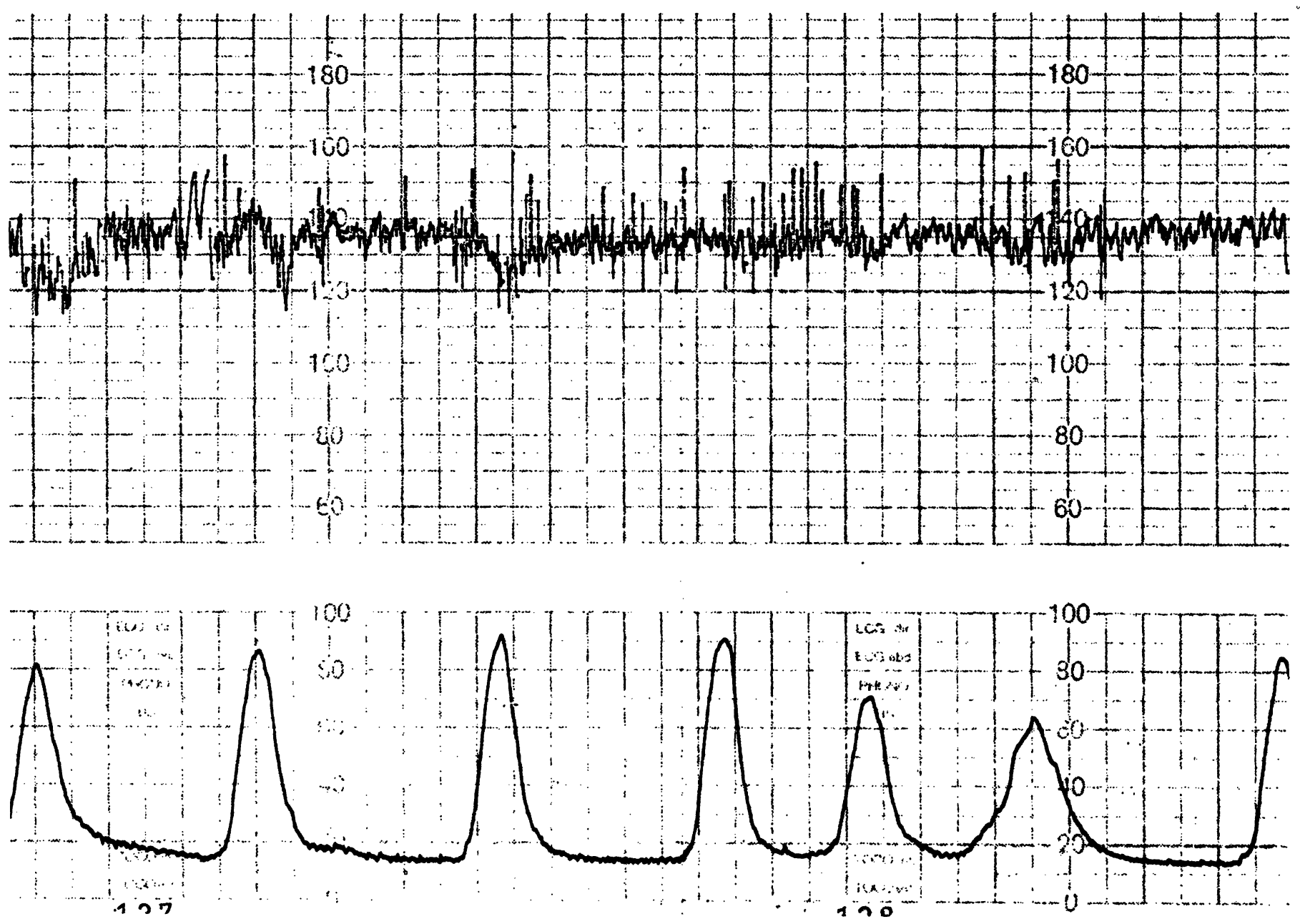

Fig. 3. Cardiographic recording of fetal extrasystoles. 


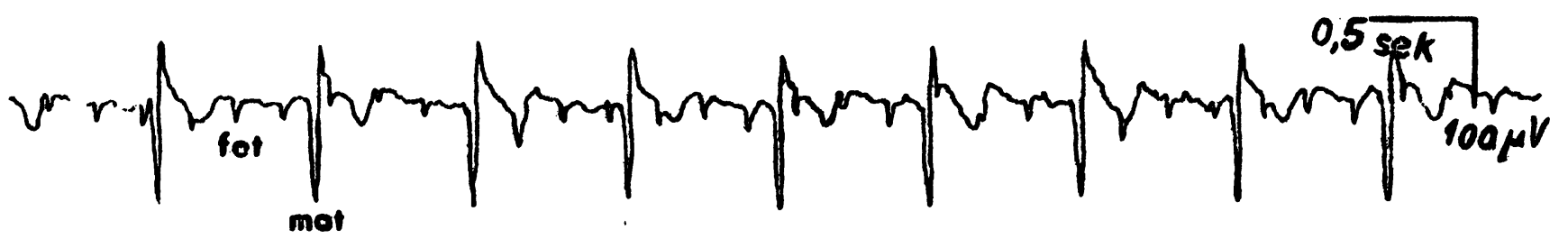

Fig. 4. Prenatal fetal ECG in the 33rd week of gestation. Fetal paroxysmal tachycardia. Rate 264-282 per minute, amplitude $32.1 \mu \mathrm{V}$.

amplitude without pen-lift (Fig. 3). These should be interpreted as fetal arrhythmias and not as artifacts which have other characteristics. After the birth of a healthy appearing girl (3700 grams, $59 \mathrm{~cm}$, APGAR score 9) the immediately recorded neonatal ECG showed occasional ventricular extrasystoles during 30 minutes. Another ECG recorded on the following day demonstrated normal sinus rhythm as did follow-up recordings. A cause for the rhythm disturbance was not found.

Case 3: N.H., 28 year-old II Para was admitted in the 33rd week of gestation because an auscultation had demonstrated an extreme fetal tachycardia of 240 to 280 beats/minute. Previously, the course of pregnancy had been unremarkable and except for an iron preparation no drugs had been taken. The maternal heart rate was normal. The fetal tachycardia persisted unchanged for 10 days. Because of the tachycardia a cardiographic recording did not succeed. The fetal ECG (Fig. 4) documented a fetal tachy-arrhythmia with a rate between 264 and 282 beats/minute. This rate was documented sonographically with a time-motion recording (Fig. 6).

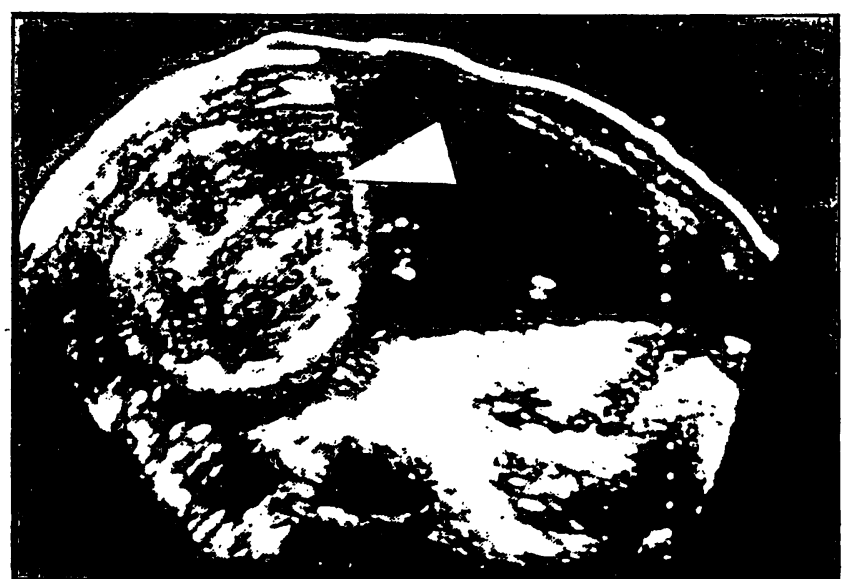

Fig. 5. Early fetal ascites in an ultrasonogram during the 33rd week of gestation. The transverse section at the level of the fetal kidneys. The arrow indicates a curvilinear layer of ascites.

J. Perinat. Med. 8 (1980)
From the ultrasonogram ascites was suspected as indication for early cardiac failure (Fig. 5); therefore the mother was treated with $\beta$-acetyldigoxin and Verapamil. $\beta$-acetyldigoxin following loading was maintained with a dose of $0.4 \mathrm{mg}$ per day and the dose of Verapamil was $80 \mathrm{mg}$ three times daily. During the four days after onset of treatment the tachy-arrhythmia slowed transiently to 180-196 per minute. Five days after complete digitalization and administration of Veramapil the fetal heart rate was normal with a rate of $138-150$ per minute. This rate persisted while therapy was continued until delivery in the 39th week of pregnancy. Delivery was induced three days before the due date. The infant ( 3200 grams, $49 \mathrm{~cm}$, APGAR score 9) had a sinus rhythm with the rate of 160-170 per minute during the first days of life. There were no signs of cardiac hypertrophy or disturbances in repolarisation. The AV conduction time was normal. Since in contrast to digoxin the Veramapil had not been shown to pass through the placenta in the human we investigated the placental passage of this substance during treatment.

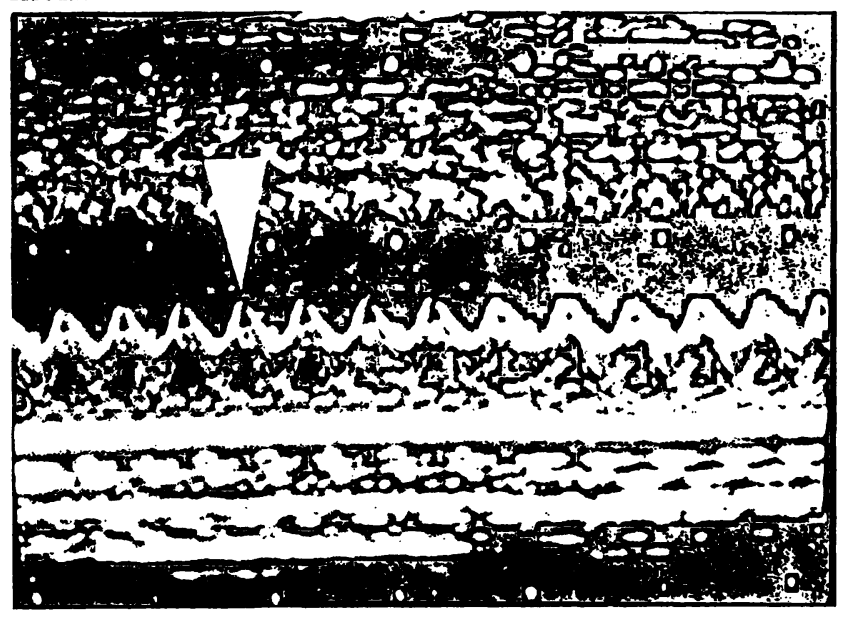

Fig. 6. Fetal cardiac activity (arrow) with the timemotion. Rate 250 per minute. The horizontal marks indicate 0.5 second intervals. 


\section{Pharmacokinetics of Verapamil}

\subsection{Materials and methods}

Six pregnant women whose deliveries were induced at term with a mature fetus and favorable cervix received during the first phase of labor $80 \mathrm{mg}$ of Verapamil orally when the cervical dilation was 3-4 cm. Infants were born between 49 and 564 minutes after the drug administration. Blood was obtained immediately after birth from the antecubital vein and the umbilical vein. Plasma samples were analyzed for concentration of Verapamil in a gas chromatograph with the nitrogen specific flame ionization detector [4]. The lower limit of sensitivity is $4 \mathrm{ng} / \mathrm{ml}$ Verapamil.

\section{: 2.2 Results (Tab. I)}

In the maternal plasma Verapamil was found up to 173 minutes after an oral dose of $80 \mathrm{mg}$. After three hours the Verapamil levels were below the detectable levels. Verapamil was found at levels of 15.4 and $24.5 \mathrm{ng} / \mathrm{ml}$ after 49 and 109 minutes. No detectable amounts of the drug were found in samples obtained later.

\section{Discussion}

The diagnosis of fetal heart rate anomalies is made from the fetal ECG. Because of physiologically low voltage it may in exceptional cases be difficult between the 29th and 35th week of gestation [1, 2]. Changes of cardiac rhythm such as a complete AV block or paroxsymal tachycardia may be recorded with the generally available cardiotocographs if the rates are not outside the range of
50-210 beats per minute. However, cardiotocograph will allow the recognition of rhythm anomalies only in cases in which the fetal signals are not rejected by the logic.circuitry which analyses signals in respect to artifacts. The Hewlett-Packard cardiograph $8030 \mathrm{~A}$ does not allow a deviation in excess of $\pm 28 \mathrm{bpm}$. Frequent unidirectional pen excursions with a constant amplitude are characteristic for arrhythmias and the signals in the oscilloscope can be diagnostically analyzed. Irregular pen excursions with frequent pen-lift on the other hand are typical for artifacts.

The incidence of persistent fetal rhythm disturbances is less than $1 \%[1,2]$. Earlier investigations [1] found in $39.5 \%$ of prenatal ECGs a variation in rhythm of more than 20 beats per minute. Disturbances of normal rates are fetal paroxysmal tachyarrhythmias as well as fetal extrasystole or complete or incomplete AV block.

Prenatally recorded fetal arrhythmias are not found after birth in $85 \%$ of the newborns. Persistent rhythm anomalies are associated with cardiac defects in less than $3 \%$ of cases $[1,2]$. The clinical importance of the diagnosis of fetal rhythm anomalies is emphasized by the fetal paroxysmal tachycardia described above. Wood [10] has shown that a persistent paroxysmal tachycardia may lead to a myocardial insufficiency. Therefore, signs of cardiac decompensation such as the sonographic documentation of ascites in the fetal abdomen should be looked for. Paroxysmal tachycardias are almost exclusively of supraventricular origin. The treatment consists of the use of Verapamil in combination with digitalis to the mother $[6,7,8]$. This treatment brings about a normalization of the heart rate by inhibiting AV conduction and prolongation of the refactory time [7].

Tab. I. Placental transfer of Verapamil after oral administration.

\begin{tabular}{lllllllll}
\hline $\begin{array}{l}\text { Interval administration* } \\
\text { delivery }\end{array}$ & $(\mathrm{min})$ & 49 & 109 & 173 & 180 & 211 & $\ldots 564$ \\
$\begin{array}{l}\text { Concentra- Mother } \\
\text { tion of }\end{array}$ & $(\mathrm{ng} / \mathrm{ml})$ & 90.0 & 95.9 & 13.7 & n.d. & n.d. & $\ldots$ & n.d. \\
Verapamil umbil. vein & $(\mathrm{ng} / \mathrm{ml})$ & 15.4 & 24.5 & n.d. & n.d. & n.d. & n.d. \\
\hline
\end{tabular}

* Oral administration of $80 \mathrm{mg}$ Verapamil.

n.d.: no determinable concentration of Verapamil. Lower limit of detection $4 \mathrm{ng} / \mathrm{ml}$ plasma. 
Valerius [11] in 1978 was the first to report a successful treatment of fetal supraventricular tachycardia by maternal digitalization. In our case we treated with $\beta$-acetyldigoxin and Verapamil in the dosages mentioned and fetal heart rate because normal during treatment.

The basis for the treatment were studies on the placental transfer of the two drugs used. Rogers [5] demonstrated that digoxin concentrations in the umbilical blood was the same as that in the maternal blood in women who received longterm digitalis treatment because of heart disease. Therefore, a free transfer of digoxin must be assumed. The placental transfer of Verpamil in humans has not been investigated before. We were able to de- monstrate placental transfer after a one time dose of $80 \mathrm{mg}$ of Verapamil during delivery.

This confirmed animal experiments by STRIGL [9]. Concentration in the fetus after one time oral administration to the mother were $15.4 \mathrm{ng} / \mathrm{ml}$ after 49 minutes and $24.5 \mathrm{ng} / \mathrm{ml}$ plasma after 109 minutes. Thus, the concentrations in the infant are markedly less than in the maternal plasma. With larger time intervals between administration and delivery no Verapamil was detected in the cord blood. The question remains open whether pharmacologically effective drug levels were achieved in the fetus while administering $240 \mathrm{mg}$ of Verapamil per day.

\section{Summary}

This study discusses the diagnosis and therapeutic possibilities of fetal heart rate anomalies in light of three case reports. A complete AV block which persisted after birth converted to normal rhythm without treatment. In the second case extrasystoles in the fetus were not present in the newborn. The third case of heart rate anomaly was a paroxysmal tachy-arrhy thmia with a rate of 264-282 per minute which was observed for ten days. In all cases the diagnosis was made with a prenatal fetal ECG. The first two disturbances were also recorded with the cardiotogram. The fetal extrasystole was manifest in the cardiotocogram by unidirectional excusions of the pen with constant amplitude and simultaneous extrasystoles on the oscilloscope. In the third case of a fetal paroxysmal tachycardia the cardiotocograph did not record the arrhythmia because the rate exceeded the range of the cardiotocograph. Because of a fetal cardiac insufficiency the mother was treated with $\beta$-acetyldigoxin and Verapamil. During this therapy the fetal heart rate became normal until delivery. We investigated the placental transfer of Verapamil because it had not been investigated previously in humans. The concentration in the umbilical venous blood 49 and 109 minutes after administration of $80 \mathrm{mg}$ Verapamil to the mother was 15.4 and $24.5 \mathrm{ng} / \mathrm{ml}$ respectively; these levels were less than those in the maternal plasma. At longer intervals between administration and delivery the Verapamil levels in the umbilical venous blood was below a detectable level. Therefore, it has been shown that Verapamil passes through the placenta.

Keywords: Fetal electrocardiogram, fetal heart rate anomalies, pharmacokinetics of Verapamil.

\section{Zusammenfassung}

Pränatale Diagnostik und Therapie fetaler Herzfrequenzanomalien. Mit einem Beitrag zur Plazentagängigkeit von Verapamil (Isoptin ${ }^{\circledR}$ )

In der vorliegenden Arbeit wird über die Diagnostik und therapeutische Möglichkeiten bei fetalen Herzfrequenzanomalien anhand von 3 kasuistischen Beispielen berichtet. Ein kompletter AV-Block, der zunächst postpartal fortbestand, normalisierte sich ohne Therapie. Im zweiten Fall einer fetalen Extrasystolie konnte diese Frequenzanomalie beim Neugeborenen nicht mehr nachgewiesen werden. Bei der dritten Herzfrequenzveränderung handelte es sich um eine über 10 Tage beobachtete paroxysmale Tachyarrhythmie mit einer Frequenz von 264-282/ Minute. In allen Fällen erfolgte die Diagnostik durch das pränatale fetale EKG. Bei den beiden erstgenannten Störungen gelang die Registrierung auch bei der Kardiotokografieaufzeichnung, wobei die fetale Extrasystolie bei der subpartualen direkten EKG-Ableitung mit der
Scalp-Elektrode durch gleichgerichtete Schreiberausschläge mit konstanter Amplitude und gleichzeitigem oszilloskopischem Nachweis der Extrasystolen gesichert wurde. Im dritten Fall einer fetalen paroxysmalen Tachyarrhythmie gelang keine kardiotokografische Registrierung, da die Frequenz der Signale den vorgegebenen Bereich überschritten. Wegen einer fetalen Herzinsuffizienz wurde eine Behandlung der Mutter mit $\beta$-Acetyldigoxin und Verapamil durchgeführt. Unter dieser Therapie gelang eine Normalisierung der fetalen Herzfrequenz bis zur Geburt. Da über die Plazentapassage von Verapamil beim Menschen im Gegensatz zu Digoxin, bei dem ein freier Übertritt bekannt ist, keine Mitteilungen vorliegen, untersuchten wir die Plazentagängigkeit dieser Substanz. Die Plasmakonzentrationen betrugen nach einmaliger oraler Einnahme von $80 \mathrm{mg}$ Verapamil durch die Schwangere unter der Geburt im Nabelvenenblut nach 49 und 109 Minuten 15,4 und $24,5 \mathrm{ng} / \mathrm{ml}$ und lagen 
damit unterhalb der Konzentrationen im mütterlichen Plasma. Bei größeren Zeitintervallen zwischen Einnahme und Geburt lagen die Verapamilkonzentrationen im Na- belschnurplasma unterhalb der Nachweisgrenze. Die Plazentagängigkeit dieser Substanz ließ sich daher auch für den Menschen sichern.

Schlüsselwörter: Fetales Elektrokardiogramm, fetale Herzfrequenzanomalien, Pharmakokinetik von Verapamil.

\section{Résumé}

Diagnostic et traitement prénataux des anomalies de la fréquence cardiaque foetale

Il est fait état, dans le présent travail du diagnostic et des possibilités thérapeutiques façe à des anomales de la fréquence cardiaque foetale, et ceci à l'aide de trois exemples casuistiques. Un bloc auriculo-verticulaire complet, qui a persisté au début de la période postnatale, a régréssé spontanément. Dans le deuxième cas une extrasystolie foetale n'a plus pu être retrouvée après la naissance. Dans le troisième cas il s'agissait d'une tachyarrhythmie paroxystique d'une fréquence se situant entre 264 et 282 battements par minute et qui a été observée pendant plus de 10 jours. Le diagnostic a été observée pendant plus de 10 jours. Le diagnostic a été posé dans tous les cas au moyen de l'ECG foetal prénatal. Dans les deux premiers cas l'anomalie a pu également être enregistrée à la cardiotocographie; l'extrasystolie foetale a été prouvée lors de la dérivation prépartale directe d'ECG à l'électrode au scalp à l'aide de signaux d'enregistrement de même sens, d'amplitude constante et de preuve oscilloscopique simultanée d'extrasystoles. Dans le troisième cas, celui de la tachyar- rhythmie foetale paroxystique, l'enregistrement cardiotocographique $n$ 'a pu être réalisé du fait du dépassement de l'intervalle d'enregistrement par la fréquence des signaux. Il a été entrepris un traitement maternel par la $\beta$-acétyldigoxine et le verapamil dont la visée était une insuffisance cardiaque foetale. Sous cette thérapeutique la fréquence cardiaque foetale s'est normalisée jusqu'à l'accouchement. Nous avons analysé la perméabilité placentaire pour le verapamil pour lequal, à l'inverse de la digoxine, il n'y a pas de données dans la littérature. Les concentrations plasmatiques dans les veines ombilicales étaient de 15.4 et de $24,5 \mu \mathrm{g} / \mathrm{ml} 49$ ou 109 minites après l'administration orale unique à la parturiente de $80 \mathrm{mg}$ de verapamil, et ainsi étaient-elles au dessous de celle du plasma maternel. Lorsque les intervalles de temps entre prișe médicamenteuse et accouchement étaient supérieurs, les concentrations veineuses funiculaires de verapamil étaient au déssous du seuil dosable. Ainsi la perméabilité placentaire pour cette substance pour l'espèce humaines s'en est-elle trouvée ainsi prouvée.

Mots-clés: Anomalies de fréquence cardiaque foetale, électrocardiogramme foetal, pharmacocinésie du verapamil.

Acknowledgement: This work is dedicated to Professor R. KAISER on his 60th birthday.

Bibliography

[1] BOLTE, A.: Die pränatale fetale Elektrokardiographie. Gynäkologie 2 (1969) 63

[2] BOLTE, A., R. BERENDES: Frequenz und Rhythmus der fetalen Herzaktionspotentiale im Verlauf der Gravidität. Geburtsh. u. Frauenheilk. 32 (1972) 635

[3] FISCHER, W. M.: Kardiotokographie. Thieme

[4] HEGE, H. G.: Gaschromatographic determination of Verapamil in plasma and urine. Arzneimittelforsch./Drug Res. 29 (1979) 1681

[5] ROGERS, M. C., J. F. WILlERSON, A. GOLDBLATT, W. SMITH: Serumdigoxin concentrations in human fetus, neonate and infant. N. Eng. J. Med. 287 (1972) 1010

[6] SCHOMER US, B., B. SIEgELHALDER, B. STIEREN, M. EICHELBAUM: Phy siological disposition of Verapamil in man. Cardiovas. Res. 10 (1976) 1

[7] SINGH, B. N., G. EllRoth, C. T. PETER: Verapamil: A review of its pharmacological properties and therapeutic use. Drugs 15 (1978) 169
[8] SPIEGELHALDER, B., M. EICHELBAUM: Determination of Verapamil in human plasma by massfragmentography using stable isotope-labelled Verapamil as internal standard. Arzn.mittelforsch. 27 (1977) 94

[9] STRIGL, R., W. ERHARDT, H. G. HEGE, G. BỬML: Untersuchungen zur Plazentapassage von Verapamil beim Meerschweinchen. Z. Geburtsh. Perinat. 183 (1979) 109

[10] WOOD, P.: Polyuria in paroxysmal tachycardia and paroxysmal artrial flutter. Brit. Herat J. 25 (1963) 273

[11] VALERIUS, N. H., J. R. JACOBSEN: Intrauterine supraventricular tachycardia. Acta Obstet. Gynecol. Scand. 57 (1978) 407

Received November 22, 1979. Revised January 28, 1980. Accepted February 18, 1980.
Dr. F. Wolff Univ.-Frauenklinik Kerpener Str. 34 D-5000 Köln 41 